811.163.41'42:27-1

811.111'42:27-1

811.163.41'367:811.111'367

https://doi.org/10.18485/sj.2019.24.1.30

ИВАНА А. КНЕЖЕВИЪ

Универзитет у Београду

Православни богословски факултет
Оригинални научни рад

Примљен: 11. 09. 2018.

Прихваћен: 15. 01. 2019.

\title{
АДАПТАЦИЈА ЛЕКСИКЕ ЦРКВЕНОСЛОВЕНСКОГ ПОРЕКЛА У НАУЧНИМ ТЕОЛОШКИМ РАДОВИМА НА СРПСКОМ И ЕНГЛЕСКОМ ЈЕЗИКУ
}

Овај рад бави се лексиком црквенословенског порекла у теолошким академским и научно-популарним радовима. Истраживање ће бити поткрепљено одговарајућим примерима добијених анализом репрезентативног корпуса еминентних аутора теолошких научних радова на српском и енглеском говорном подручју. Поред тога, биће спроведена и статистичка анализа датих текстова како би се истраживање употпунило и конкретним процентуалним подацима.

Кључне речи: теолингвистика, славистика, стилистика, црквенословенска лексика, адаптација, теолошки радови.

0. Свака грана науке има себи својствену терминологију у складу са предметом и методом свога истраживања. Терминологија је срж научног стила, последњи, унутрашњи круг, најистакнутије обележје језика науке. Прецизан начин изражавања коме се тежи огледа се у великом уделу терминолошке лексике. Термини се по својој природи разликују од обичних речи. Термин је реч или синтагма, која тачно и једнозначно именује предмет, појаву или идеју науке и открива њен садржај; у основи термина налази се научно саздана дефиниција. М. М. Глушко констатује да је термин „реч или синтагма за изражавање појма и означавање предмета, који захваљујући строгој и тачној

*iknezevic@bpspc.bg.ac.rs 
дефиницији која је у њему присутна, садржи јасне семантичке границе и тиме је једнозначан у области одговарајућег класификационог система" (Глушко et al. 1974). А. А. Реформатски одређује термин као „једнозначну реч, лишену експресивности" (Реформатский 1955). Термини су, дакле, речи које означавају логички формулисане појмове и носе логичну информацију највишег степена (Чаркић 2002: 170).

Термин не треба да има синониме, већ тежи моносемичности како би у свести лакше призвао одређени концепт на који се односи. Термину „не приличи" емоционалност, метафоричност, присуство било каквих асоцијација, итд. (Коммисаров 1990: 110-111).

Термини су карактеристични за научни стил, али се употребљавају и у другим функционалним стиловима (публицистички, књижевни, и др.), када се њихова функција мења (указују на техничке особености појаве о којој је реч, на компетентност особе, и сл.).

1. Специфична методологија теологије као и особености њеног научног познања неминовно утичу на ванјезичка и унутарјезичка обележја теолошких научних радова, а поље лексике јесте највидљивији показатељ. Будући да природа научног израза тежи прецизности и лапидарности, за науку уопште неминовна је употреба терминолошке апаратуре. У свим, па и у теолошким научним радовима у оквиру терминологије издвајају се две подгрупе: 1. општенаучна терминологија, и 2. номенклатурна или ускостручна терминологија - терминологија карактеристична за једну ужу научну област (у овом случају теологију).

Будући да је лексички слој језика најпроминентнији представник сваке науке понаособ, то се и најочигледније разлике између научих радова из области теологије и других научних области не огледају се толико у морфолошким и синтаксичким особеностима научног текста, већ су изразито истакнуте у домену лексике. Сам предмет научног истраживања сваке области науке намеће одговарајућу ускостручну терминолошку лексику карактеристичну за дату област. Такав је случај и са теологијом. Међутим, у ускостручну терминологију могу ући и:

1. општеупотребне речи са суженом полисемијом;

2. фразеологизми (фразеолошке јединице терминолошког карактера; по саставу то су фразеологизми типа синтагме - вишечлани називи научих појмова који се у научном стилу врло често сматрају само вишечланим терминима а не фразеологизмима);

3. интернационализми (првенствено пореклом из латинског и грчког, али и хебрејског језика, и прилагођени углавном процесом транскрипције или су фонолошко-морфолошки адаптирани у енглеском, односно у српском језику); 
4. речи страног језика (у форми речи, фраза, конструкција, најчешће преузете из оригиналног извора); као и

5. црквенословенизми.

2. Овим радом ограничили смо се на истраживање ускостручне лексике црквенословенског порекла у теолошким ускостручним научним и научно-популарним радовима, и истраживање поткрепили одговарајућим примерима добијеним анализом репрезентативног корпуса еминентних аутора теолошких научних радова. Поред тога, спроведена је и статистичка анализа датих текстова како би се истраживање употпунило и конкретним процентуалним подацима.

Термином „црквенословенизми” означене су речи и особине које припадају црквенословенској лексици, укључујући и разне позајмљенице, а такође и хибридне творевине, тј. облике који садрже особине и црквенословенског и српског језика (Стијовић 1992: 13).

Битно својство, богатство и посебан слој лексике теолошких радова лексике теолошких радова чине бројни црквенословенизми. Међу њима има и термина - углавном ускостручних, и не нужно преведеница са грчког. Међутим, они прожимају језик научних радова и на нивоу општеупотребне лексике, повезујући га на тај начин са радовима религијског стила (в. Бугаева 2005: 3-11; Кнежевић 2010), чинећи га посебним, битно другачијим од стила радова других области науке. Црквенословенизми су у српском језику фонолошко-морфолошки адаптирани или понекад и пресликани у својој оригиналној форми. У овом потоњем облику појављују се најчешће у строго научним радовима - када су намењени стручњаку од кога се очекује да их у оваквој форми без потешкоћа усвоји.

У црквенословенизме који су у анализираним ускостручним научним радовима фонетско-фонолошки адаптирани убрајају се, на пример: благочешће и всецели (blagočestie, vseceli):

Свети Григорије Богослов, у свом познатом V Теолошком слову, каже да се наше хришћанско благочешће (тј. хришћанска вера и побожност) утемељују у Духу Светоме, да од Њега и почиње истинска теологија (Јевтић 1990: 5).

Аутор у загради појашњава значење датог црквенословенизма. Ова лексема - благочешће - може се третирати и као лексички хибрид који у себи садржи и црквенословенске - формант благо- који открива семантичке одлике црквенословенизама - и српске црте: рефлекс суфикса.

Управо зато што је Христос у Духу Светоме истог часа благоизволео да Он свецели буде и бива тај Хлеб и та Крв: сушта евхаристија (Лубардић 2001: 63). 
Свецели је хибридни облик на бази црквенословенизма где је дошло до метатезе у иницијалном слогу под утицајем стања још у старосрпском језику.

Или у раду Евхаристијска теорија личности и православна веронаука имамо:

Вероучитељ прво „рађа” христообразне личности а то, уједно, тражи развијање способности за личносност (=

Христообразни је црквенословенизам, а по свему судећи је у црквенословенском настао калкирањем са грчког (калк у српском језику гласи: христолик, христоликост).

Или у раду Духовност православља:

Василије ту описује како је, и зашто, он почео да употребљава једну боље одговарајућу и богословски тачнију доксологију (=литургијски возглас, славослов) Свете Тројице (Јевтић 1990: 11).

Аутор у горе наведеном примеру објашњава значење ускостручног термина доксологија номенклатурама-црквенословенизмима датим у загради, од којих је други термин - славослов - калк са грчког.

Ова мисијска или икономијска страна („Икономија” у библијском смислу: Oıкоvo $\mu 1 \alpha$ као код Апостола Павла) или улога Духа Светога, показује Његово место и делатност у општем промисаоном плану или Домостроју Божијем, почев од самог стварања света па све до доласка реалности будућег века (Јевтић 1990: 8).

Лексема домострој јесте црквенословенизам лексички реализован калкирањем према грчком икономија пресликавањем структуре оригиналног израза.

Дух Свети као „Невестоукраситељ” Цркве Христове, остварује се у њој, за нас у свету, присуство и предокушај есхатолошке Тајне Божије, и само благодарећи том дејству Духа у Цркви ми се истински причешћујемо Христом Богочовеком, ступамо у стварну заједницу и општење са Оцем, са Светом и Животворном Тројицом (Јевтић 1990: 17).

За употребљени пример у облику благодарећи може се рећи да је типичан пример црквенословенизма са српском фонетском и морфолошком адаптацијом (формант благо- открива семантичке одлике црквенословенизама).

Или, црквенословенизми употребљени просто у транслитеризованој форми, као што су лексички облици свјатим, богословије:

Да од Духа Светога заиста и започиње теологија, то потврђује и богослужбена песма Православне Цркве: „Свјатим Духом богословије...” (Јевтић 1990: 5).

„Свјатим Духом богословије...” јесте редак пример реченице на црквенословенском која је транслитерацијом пренета у српски језик и представља 
инципит једне богослужбене песме, познате не само аутору, већ, претпоставља се, и читаоцима.

\section{Или пример лексеме битије такође пренет у транслитеризованом лику:}

Наиме, проблем који се намеће у вези са питањима постављеним на почетку текста јесте: да ли се термини „битије” ( односе на: 1) Бога, или 2) божанске силе - од којих је овде за наш проблем централна, већ

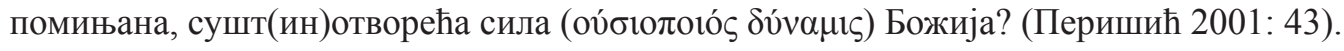

3. Након досадашњег излагања представићемо резултате статистичке анализе датих научних радова. Анализа је спроведена на корпусу од хиљаду речи сваког појединачног рада, како би се утврдила процентуална заступљеност ускостручних, и удела црквенословенизама у фонду ускостручне терминологије.

Номенклатурна терминологија заступљена је просечно око 17\% од целокупне лексике, и то у Личност и суштина у теологији светог Григорија Паламе око 15\%, у Духовност православља око 20\%, а у Евхаристијска теорија личности и православна веронаука око $16 \%$.

У строго научним радовима црквенословенизми просечно чине око $2 \%$ од укупног броја ускостручних термина, и то у Личност и суштина у теологији светог Григорија Паламе око 3\%, у Духовност православља око 1\%, а у Евхаристијска теорија личности и православна веронаука око 0\%.

4. Радови научно-популарног подстила по својим стилским карактеристикама налазе се на самој граници научног стила, попримајући елементе осталих стилова - најчешће књижевноуметничког, али и разговорног, у зависности од жанра, теме која се третира, као и од индивидуалности самог аутора. Следствено томе, радови научно-популарног подстила стилски су најудаљенији од радова строго научног стила, односно неке доминантне црте строго научног стила овде су присутне у мањој мери или готово одсутне.

У анализираном узорку, црквенословенизми су потпуно одсутни у радовима на енглеском језику, али се и у узорку радова на српском готово уопште не појављују. Ретке примере црквенословенизама налазимо само у Православном катихизису:

Мана је била предуказање Свете Тајне Причешћа Крвљу и Телом Христовим, Хлебом који силази с небеса и даје се за живот света (Крстић \& Радовић, 2003: 18)

Његово рођење благовести Архангел Гаврило поздрављајући Пресвету Деву небеским поздравом: „Радуј се благодатна, Господ је с тобом, благословена си ти међу женама!” (Крстић, Радовић 2003: 22).

Сложеница предуказање и реч благовестити су, према Речнику српског језика, црквенословенизми.

Христова смрт је извор нашег вечног живота кроз измирење са Богом („Смерт бо твоја живот мој”), а Христово васкрсење је основ и залог нашег васкрсења за живот вечни (стр. 2). 
Ово је редак пример реченице на црквенословенском која је транслитерацијом пренета у српски језик.

У књизи под насловом Living Prayer аутор уводи речи црквенословенског порекла прилагођене истовремено и транслитерацијом и транскрипцијом енглеском језику и објашњава њихово значење и порекло:

The words milost and pomiluy in Slavonic have the same root as those which express tenderness, endearing, and when we use the words eleison, 'have mercy on us', pomiluy, we are not just asking God to save us from His wrath - we are asking for love (Bloom 1966: 87).

Већину речи којима су превођени називи за специфичне реалије Православне Цркве чине стране речи или позајмљенице. Оне су углавном дошле из грчког језика, а нешто ређе из црквенословенског, односно руског језика. Прилагодиле су се енглеском језику углавном неком врстом „адаптиране транслитерације", или комбиновањем поступака транскрипције и транслитерације. Услед неподударности између графолошких система енглеског језика, као језика циља са једне стране, и грчког, црквенословенског и руског, као изворног језика са друге стране, сам процес транслитерације није било могуће доследно применити. Исти је случај и са процесом транскрипције, који ће се ретко употребљавати сам, из разлога што постоје ограничења и у преношењу свих фонолошких вредности из једног језика у други. Комбиновањем ова два поступка, или, како смо ми то назвали, „адаптираном транслитерацијом” добијене су следеће посуђенице: Kormchaya kniga, plastanica, Vidovdan, slava = слава, крсно име, starets = старац (у смислу: духовник) и друге.

Преводилачки процес калкирања је врло ретко примењиван у превођењу безеквивалентне лексике која се овде испитује. На овај начин добијена је нпр. лексема name-day = имендан.

Испитивани корпус показује да се радије прибегава употреби страних речи за преношење безеквивалентне лексике из језика у језик, него калкирању. Калкирање би био далеко прихватљивији поступак када се преводи за просечне примаоце превода. Таквим читаоцима било лакше да прате основни садржај текста, а да се том приликом не умарају упућивањем на објашњења у напоменама или, за њих, сувишним и неинтересантним информацијама које би биле додате у самом тексту. Препоручљиво би било да се већина сложеница као оне које смо горе навели као стране речи или туђице које су дошле из грчког или црквенословенског, калкирају, односно преведу домаћим елементима, тј. елементима из енглеског језика,пресликавањем структуре оригиналног израза, па да у таквој форми уђу у енглески језик. Разлога има више. Прво, тиме би се оне лакше и брже адаптирале и асимиловале у општи речник енлеског језика. Друго, њихова употреба и разумевање било би олакшано како неправославним тако и православним верницима којима грчки односно црквенословенски језик није познат, па тиме ни значење страних сложеница које су из ових 
језика дошле. Тако би, на пример назив за песму многољетство могао бити преведен као for/on-many-year-song или, како налазимо код владике Николаја (Velimirovich 1951), long life!, уместо polychronion; или ставрофор као cross/bearer, уместо stavrophor.

Назив за зборник црквених и световних прописа за црквену управу и судство у православној Цркви - Крмчија - црквенословенског је порекла и значи „крма”, „кормиларска књига”. Један од понуђених превода на енглески језик је Rudder, што у преводу такође значи „крма”. Ове речи у енглеском језику односе се углавном на реалије из свакодневног живота и немају и оно уже значење као њихови еквиваленти у српском језику. У контексту теолошких текстова и оних из области православне духовности ови термини добијају своје ново, уже значење и у преводу на енглески језик. Просечном примаоцу превода ово ново значење може ипак остати непознато. Разлика у значењу у односу на њихов општи смисао може се истаћи и ортографијом, тако што ће се писати великим словом, какав је случај са речју Rudder, Air, Holy Shroud. Ако се термин, који има опште значење „ваздух” у писменом преводу пише великим словом, он тиме у датом контексту добија посебно значење богослужбеног предмета. У неким случајевима пожељно би било додатно објаснити термин у самом тексту превода. Тако се лахан може превести као church vessel bowl или само church vessel, чиме би се указало да се ради о црквеном сасуду за посебне намене. Уз термин Rudder имамо додатак „оf the Orthodox Christians", који упућује на ново значење које је ова реч добила и тако јасније и прецизније указује о каквој је реалији реч.

Ево неколико речи црквенословенскога порекла које су прилагођене енглеском језику процесом:

a) транслитерације, као нпр. речи: Jeromonah, Lavra, Konak, the Sabor = Сабор, Spasovdan = Вазнесење Господње, Спасовдан и др;

б) транскрипције: chrysovulla и др; или

в) комбинацијом ова два поступка, такозваном „адаптираном транслитерацијом": Postnitza, Mislioniza и сл.

5. После изложене анализе приступамо, у закључку, свођењу резултата истраживања ускостручне лексике словенског порекла у теолошким ускостручним научним и научно-популарним радовима. Употреба црквенословенизама у теолошким радовима (као и интернационализама - латинизама, грцизама, хебраизама) било у транслитерализованој било у пресликаној форми оригиналног облика, даје научном тексту тон озбиљности, одвојености и уникатности, и оставља утисак „високог стила”. Некада су овакве пресликане форме речи или конструкције уткане у само ткиво научног текста, са преводом или без њега, или са објашњењем значења у даљем току текста или у загради, и присутне су пре свега у строго научним текстовима. 


\section{ИЗВОРИ}

Bloom 1966: Anthony Bloom, Living Prayer, Templegate Publishers, Springfield, IL.

Јевтић 1990: Атанасије Јевтић, Духовност православља, Храст, Београд.

Крстић/Радовић 2003: Данило Крстић, Амфилохије Радовић, Православни катихизис, Београд: Хришћанска мисао.

Лубардић 2001: Богдан Лубардић, Евхаристијска теорија личности и православна веронаука. Богословље, год. LXV (LIX), бр. 1-2: 49-105.

Перишић 2001: Владан Перишић, Личност и суштина у теологији светог Григорија Паламе, у: Свети Григорије Палама у историји и садашњости: 41-50, Србиње: Духовна академија Светога Василија Острошког.

Velimirovich 1951: Nikolai Velimirovich, The Life of St. Sava, Libertyville: Serbian Orthodox Monastery of St. Sava.

\section{ЛИТЕРАТУРА}

Бугаева 2005: И. В. Бугаева, Стилистические особенности и жанры религиознойсферы., у: Стилистика текста. Межвуз. Сборник научных трудов, Н. Новгород: НГЛУ им. Н. А. Добролюбова, 3-11.

Глушко 1974: М. М. Глушко et al. Функииональный стиль общественного языка и методы его исследования. (http://bibliofond.ru/ view. aspx?id=14204)

Кнежевић 2010: Ивана Кнежевић, Теолошки дискурс енглеског и српског језика: лексичко-семантички и стилистички проблеми превођења, Београд: Православни богословки факултет Универзитета, Институт за теолошка истраживања.

Коммисаров 1973: В. Н. Коммисаров, Слово о переводе, Москва: Международные отношения.

Реформатский 1955: А. А. Реформатский, Введение в языкознание, Приступљено 23.12.2011. (http://bibliofond.ru/ view.aspx?id=14204)

PCJ 2007: Речник српског језика, Нови Сад: Матица српска.

Стијовић 1992: Светозар Стијовић, Славенизми у Његошевим песничким делима, Сремски Карловци, Нови Сад: Издавачка књижарница Зорана Стојановића.

Чаркић 2002: Милосав Чаркић, Увод у стилистику, Београд: Научна књига. 


\section{ADAPTATION OF LEXIS OF CHURCH-SLAVONIC ORIGIN IN ACADEMIC THEOLOGICAL WORKS IN SERBIAN AND ENGLISH LANGUAGES}

\section{Summary}

This study indicates that each branch of science, including theology, has a particular terminology in accordance with the object and method of its research, and it is the most distinctive characteristic of the language of science. In this work, the authors limited themselves to the study of nomenclatures of Slavonic origin in the theological academic papers. Numerous Slovenian neologisms represent the essential characteristic, richness and a special layer of lexis of theological works. They permeate the language of scientific papers at the level of generally used lexis, linking it in this way with the works of religious style, and making it special and very different from the style of the works of other fields of science. In Serbian language they are phonologically and morphologically adapted or sometimes copied in its original form, while in the English language they are adapted mainly by the means of a kind of "adapted transliteration", or the combination of methods of transcription and transliteration.

Key words: theolinguistics, stylistics, nomenclatures, Slovenian neologisms, theological academic papers. 